\title{
ANALYSIS OF PRECIPITATION YEAR TYPES AND THEIR REGIONAL FREQUENCY DISTRIBUTIONS IN THE DANUBE-TISZA MID-REGION, HUNGARY
}

\author{
A. KUN \\ Inst. Ecology and Botany, Hungarian Academy of Sciences, H-2163 Vácrátót, Hungary; \\ E-mail:kun@botanika.hu
}

(Received 19 January, 2001)

\begin{abstract}
The precipitation distribution of the Hungarian part of the Danube-Tisza Mid-Region (the centre of the Great Hungarian Plain) is discussed based on 70 years of monthly data from eleven meteorological stations. The vegetation of the region belongs to the southeast Central European forest-steppe zone. Besides the edaphic conditions, the vegetation is primarily constrained by the amount and seasonal distribution of precipitation. Precipitation year-types defined by the annual sums and the seasonal distribution of precipitation including the time of maximum and minimum amounts within year were used to compare the climate of the stations. Great differences were found between the northern and southern part of the region in the frequency distributions of precipitation year types. Years with high amount of precipitation were more frequent at the northern part of the region, while years with low amount of precipitation were more frequent at the southern part. The number of years with low summer precipitation is also increased from north to south.

Within this overall north to south gradient, two parallel gradients were distinguished in the western and the eastern part of the region. Along the western gradient, years with higher annual and summer precipitation had a higher frequency compared to the eastern gradient. Along both gradients, however, both annual and summer precipitation decreased towards the central part of the region.

The two gradients revealed by the precipitation year types correspond with chorological-floristical and coenological gradients detected by other studies in the region. Thus, our results may provide an explanation for these changes in the flora and the vegetation of the Danube-Tisza Mid-Region.
\end{abstract}

Key words: climatic gradient, vegetation, semiarid region, distribution of precipitation

\section{INTRODUCTION}

The collin and plain vegetation of the central part of the Carpathian Basin is in many ways related to the Southeast and East European steppe and forest-steppe vegetation. On the potential vegetation map drawn by Zólyomi (1973-74), as well as by Horvat et al. (1974), the region of the Great Hungarian Plain belongs to the southeast Central European forest-steppe zone. 
Several arguments have been raised for and against this relation in the wide spectrum of literature devoted to the origin and relations of the Pannonian flora and vegetation. It is discussed in detail by Borhidi (1998), who one hand gives a review on the earlier theories, and on the other hand, takes sides in the main issues under dispute based on the latest results. He concludes that the zonal vegetation of the Great Hungarian Plain is not uniform, neither in its origin, nor in terms of its present features. The different regions of the Great Hungarian Plain differ in their edaphic, climatic, and historical features. Within the Danube-Tisza Mid-Region, for example, a strong continental influence can be detected in the closed-canopy forests and tall grass steppes of the northern part, particularly in the Gödöllő Hills (Fekete 1965), whereas sub-Mediterranean forest-steppe with opencanopy forests and short grass steppes are the potential vegetation in the southern part.

A wide transitional zone occurs between these two main types of foreststeppe vegetation in the Danube-Tisza Mid-Region. This transition in the forest-steppe biome was revealed and described in intensive studies during the last years by using chorological-floristical (Fekete et al. 1999a), phytocoenological and landscape ecological (Kovács-Láng et al. 1999, Fekete et al. 1999b, 2000), and microcoenological approaches (Bartha et al. 1999).

In this study, we investigate the patterns in the distribution of precipitation in the Hungarian part of the Danube-Tisza Mid-Region. Since water is one of the most important limiting factors in semiarid regions that influence vegetation characteristics and transitions, knowledge on the seasonal distribution of precipitation may contribute to understand the development of this transitional vegetation zone.

\section{MATERIALS AND METHODS}

In the Hungarian part of the Danube-Tisza Mid-Region, which in most parts is covered by calcareous sand, a northwest to southeast climatic gradient has been detected. Change in climate was described by a gradual increase in the value of semiaridity-index (Borhidi 1961, 1993). Borhidi's semiaridity index measures the relative lack of precipitation by the ratio of the area of humid to the area of arid period, as drawn on the Walter's climate diagram. An increase in the value of the index exhibits an increase in the relative lack of precipitation. Within the forest-steppe zone of the Danube-Tisza Mid-Region, the value of semiaridity index increases from three in the north to seven in the centre and in the south. 
The present study is aimed to explore this climatic transition in detail. 70 years (1901-1970) data of monthly precipitation measured at eleven meteorological stations were analysed. Data were obtained from Hajósy et al. (1975). Of the eleven stations studied eight are located in the Hungarian part of the Danube-Tisza Mid-Region, two (Budapest, Gödöllő) at the northern edge of this region, and one (Győr) in the Little Hungarian Plain (Fig. 1).

The seventy years were classified one-by-one and station-by-station according to the monthly precipitation amounts. Classification was based on Zólyomi's method (1958, and Zólyomi et al. 1992a, 1992b, 1997), which is a developed form of the climate-year concept of Köppen $(1918,1929)$ and Russel (1934). The very core of this approach is to take the time and amount of precipitation maximum and minimum, as well as the annual sum of precipitation into account. The method facilitates the analysis of one of the most important factors that constrain and regionally differentiate the vegetation, namely the seasonal distribution of the precipitation.

If only long-term mean annual precipitation was used for comparing sites or detecting a climatic gradient, then the most important feature of semiarid climate, the seasonal distribution of precipitation would be lost.

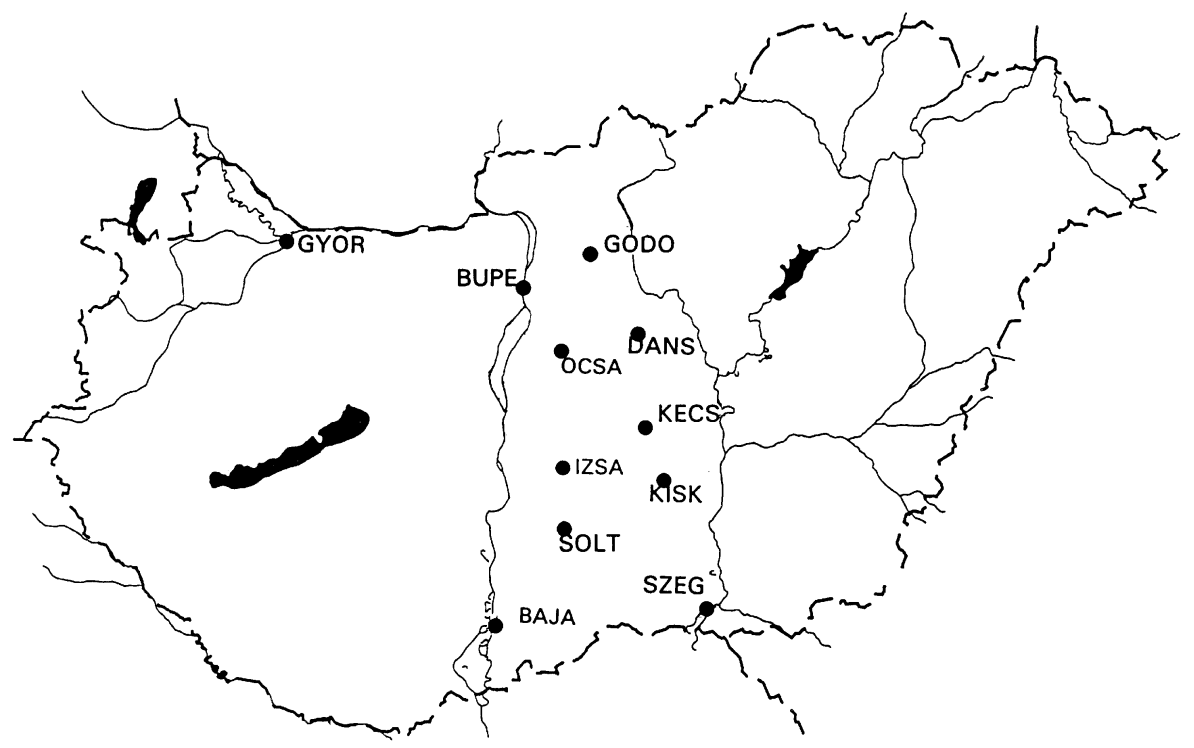

Fig. 1. Meteorological stations involved in the study in Hungary. GYOR = Győr, GODO = Gödöllő, BUPE = Budapest, DANS = Dánszentmiklós, OCSA = Ócsa, KECS = Kecskemét, IZSA = Izsák, KISK = Kiskunfélegyháza, SOLT = Soltvadkert, SZEG = Szeged, BAJA = Baja 
KUN, A.

Table 1

Precipitation year types in the Carpathian Basin, after Zólyomi et al. (1992a, 1997)

\begin{tabular}{|c|c|c|c|c|c|c|c|}
\hline Type & $\begin{array}{l}\text { Reference } \\
\text { station }\end{array}$ & Maxi & um & Mir & imum & Climate types & $\begin{array}{l}\text { Mean an- } \\
\text { nual pre- } \\
\text { cipitation }\end{array}$ \\
\hline$x^{\prime \prime}$ & Toulouse & IV-V & $X-X I$ & I-II & VII-VIII & $\begin{array}{l}\text { Atlantic-sub- } \\
\text { Mediterranean }\end{array}$ & $600-700$ \\
\hline$x^{\prime \prime} f f$ & Sarajevo & V-VI & IX-X & I-II & XI-XII & $\begin{array}{l}\text { Atlantic-sub- } \\
\text { Mediterranean }\end{array}$ & 750-900 \\
\hline$x x^{\prime \prime}$ & Varna & V-VI & XI & & I-IX & $\begin{array}{l}\text { Pontic-sub- } \\
\text { Mediterranean }\end{array}$ & $550-650$ \\
\hline BSx" & Madrid & $\mathrm{V}-(\mathrm{VI})$ & IX-X & & -VIII & $\begin{array}{l}\text { Pontic-sub- } \\
\text { Mediterranean }\end{array}$ & $400-450$ \\
\hline BSxx" & Varna & (VI) & XI & & I-IX & $\begin{array}{l}\text { Pontic-sub- } \\
\text { Mediterranean }\end{array}$ & $450-550$ \\
\hline$f, f x$ & $\begin{array}{l}\text { Warsaw, } \\
\text { Krasnodar }\end{array}$ & VI-VI & -VIII & I-II-III & $\begin{array}{l}\text { X-XI-XII } \\
\text { (IX) }\end{array}$ & $\begin{array}{l}\text { European- } \\
\text { continental }\end{array}$ & $550-750$ \\
\hline BSf & Kishinev & VI-VI & -VIII & I-II-III & X-XI-XII & $\begin{array}{l}\text { European- } \\
\text { continental }\end{array}$ & $400-450$ \\
\hline
\end{tabular}

However, the vegetation is likely to be sensitive to water availability at a monthly rather than a yearly time scale.

To define the relevant precipitation year types in the Carpathian Basin, Zólyomi et al. (1992a, 1997) selected reference stations for each of these types from geographical regions where these types are characteristic. The precipitation year types and their reference stations are shown in Table 1.

\section{RESULTS AND DISCUSSION}

The relative frequency of the precipitation year types at the eleven stations is shown in Table 2.

Results are also presented in figures. For clarity, precipitation year types that represent major climate types are plotted separately. Figures $2 a, 2 b$ and 2c show that the Danube-Tisza Mid-Region is severely affected by all three major climate types, the Atlantic-, Pontic-sub-Mediterranean, and continental climates. Changes in the share of these types within the region may provide an insight into how precipitation distribution affects vegetation.

Results show that precipitation distribution changes considerably from north to south in the Danube-Tisza Mid-Region, towards the centre of the Carpathian Basin. The frequency of Atlantic-sub-Mediterranean $\boldsymbol{x}^{\prime \prime} f f$ 
Table 2

The relative frequency (\%) of precipitation year types at the eleven stations on the basis of 70 years (1901-1970)

\begin{tabular}{lccccccccccc}
\hline $\begin{array}{l}\text { Year } \\
\text { type }\end{array}$ & GYOR & GODO & BUPE & DANS & OCSA & KECS & IZSA & KISK & SOLT & SZEG & BAJA \\
\hline $\mathrm{x}^{\prime \prime}$ & 19 & 22.7 & 28.6 & 21.4 & 23 & 19.8 & 21.4 & 18.6 & 18.6 & 23 & 17.1 \\
$\mathrm{x}^{\prime \prime} \mathrm{ff}$ & 14 & 12.9 & 12.9 & 10 & 5.7 & 7 & 4.3 & 7.2 & 7.1 & 11.4 & 10 \\
$\mathrm{xx}^{\prime \prime}$ & 17 & 16 & 14.3 & 14.3 & 14.3 & 8.2 & 5.7 & 10 & 14.3 & 10 & 18.6 \\
BSx" & 4.3 & 7.2 & 8.2 & 12.8 & 14.3 & 30.8 & 20 & 20 & 15.7 & 11.4 & 8.6 \\
BSxx" & 10 & 10 & 8.6 & 8.6 & 8.6 & 3 & 8.6 & 7.2 & 10 & 10 & 4.3 \\
$\mathrm{f}, \mathrm{fx}$ & 21.4 & 24.3 & 20 & 20 & 18.5 & 15.2 & 20 & 20 & 21.4 & 15.7 & 27.1 \\
BSf & 3 & 4.1 & 3 & 7.1 & 7.2 & 8 & 14.3 & 11.4 & 10 & 13 & 7.2 \\
$?$ & 11 & 2.8 & 4.3 & 5.7 & 8.2 & 7.8 & 5.4 & 5.6 & 2.8 & 5.3 & 7.1 \\
\hline
\end{tabular}

GYOR $=$ Győr, GODO = Gödöllő, BUPE $=$ Budapest, DANS $=$ Dánszentmiklós, OCSA = Ócsa, KECS = Kecskemét, IZSA = Izsák, KISK = Kiskunfélegyháza, SOLT = Soltvadkert, SZEG = Szeged, BAJA = Baja

years characterised by high rainfall amount (750-900 $\mathrm{mm}$ ) decrease, whereas the share of the $x^{\prime \prime}$ years characterised by typically dry summers and lower annual precipitation $(600-700 \mathrm{~mm})$ shows almost no change in the Danube-Tisza Mid-Region (Fig. 2a).

The share of $x x^{\prime \prime}$ years of the Pontic-sub-Mediterranean group, which have relatively high annual precipitation $(550-650 \mathrm{~mm})$ decreases, whereas the frequency of $\boldsymbol{B} S \boldsymbol{x}^{\prime \prime}$ years described by dry summers and low annual precipitation (400-450 $\mathrm{mm}$ ) shows a sharp increase in the central part of the region (Fig. 2b). The extremely high proportion of the latter in the region of Kecskemét, Izsák, and Kiskunfélegyháza is unique in the Carpathian Basin and is one of the most important features of the climate of the Danube-Tisza Mid-Region (cf. Zólyomi et al. 1992). The share of $B S x x^{\prime \prime}$ years having late autumn precipitation maximum and low annual sum $(450-550 \mathrm{~mm})$ is the lowest in the central part of the region and shows a slight increase followed by a decrease towards the south.

The $f$ and $f x$ years of the European-continental group, which are characterised by summer precipitation maximum, have a similar share across the region, except for Kecskemét where its share is lower compared to other stations. The increase in the importance of dry, steppe-like $\boldsymbol{B} \boldsymbol{S} f$ years in this central part of the region indicates that the influence of continental steppe climate is stronger here than in other parts of the Danube-Tisza Mid-Region. 

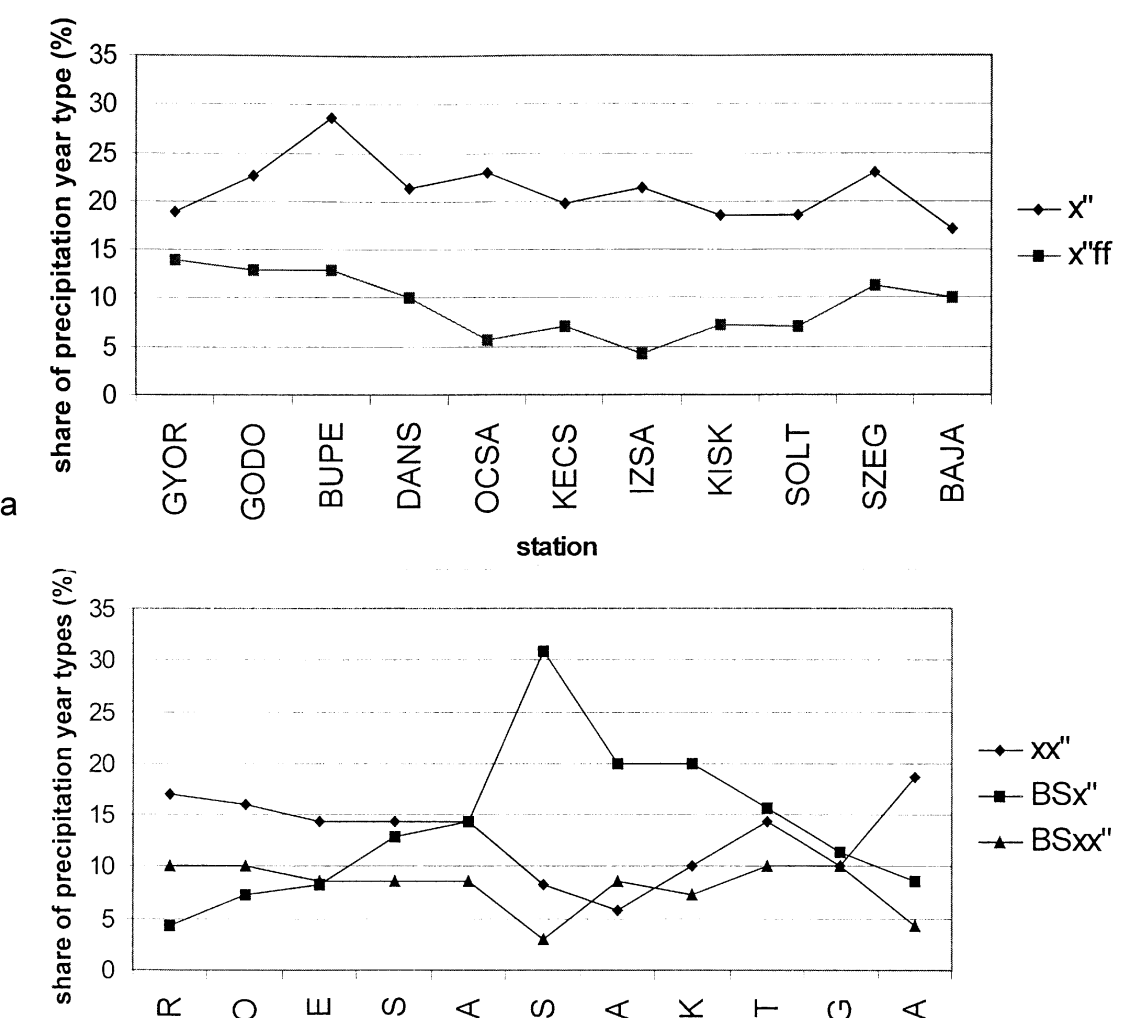

b

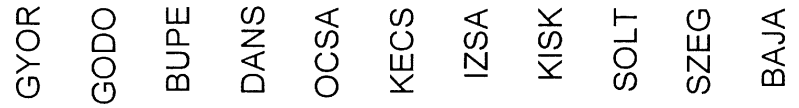

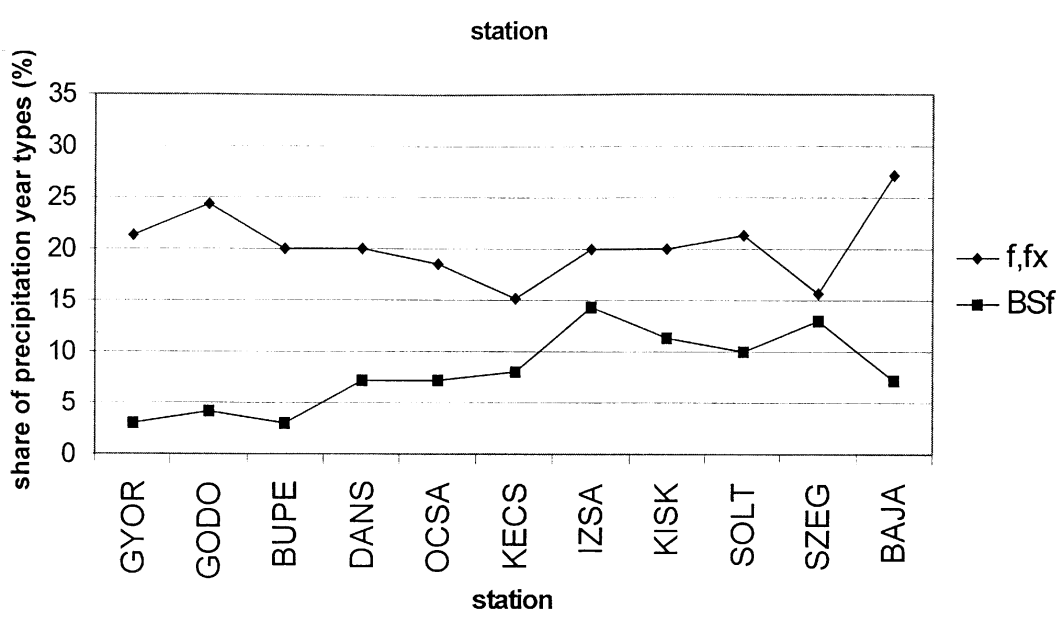

Fig. 2. $\mathrm{a}=$ Share of Atlantic-sub-Mediterranean years at the eleven stations. $\mathrm{b}=$ Share of Pontic-sub-Mediterranean years at the eleven stations. $c=$ Share of European-continental years at the eleven stations 
Our results illustrate that the basin effect is well developed in the Hungarian part of the Danube-Tisza Mid-Region. It is the central part of the region where years with dry summer and low annual precipitation reach their highest frequency. This pattern correlates well with patterns in vegetation characteristics (cf. Kovács-Láng et al. 1999).

The mean annual precipitation was also calculated over the 70 years for the eleven stations (Fig. 3). The results show a decrease with fluctuations in the mean annual precipitation towards the centre of the region.

According to the above results, the decrease in the yearly means comes mainly from a decrease in summer precipitation. Figure 3 reveals that there is a strong fluctuation between the neighbouring stations. Considering the geographical positions of these stations (Fig. 1), we hypothesize two parallel precipitation gradients, one at the eastern part and one at the western part of the region.

The mean annual precipitation shows clearly these gradients, both running from north to south (Figs $4 \mathrm{a}$ and $4 \mathrm{~b}$ ). The main difference between them is that the annual precipitation is $35 \mathrm{~mm}$ lower on an average in the eastern part of the region compared to the western part along the Danube. The difference is the smallest at the dry central part of the region and increases both southward and northward.

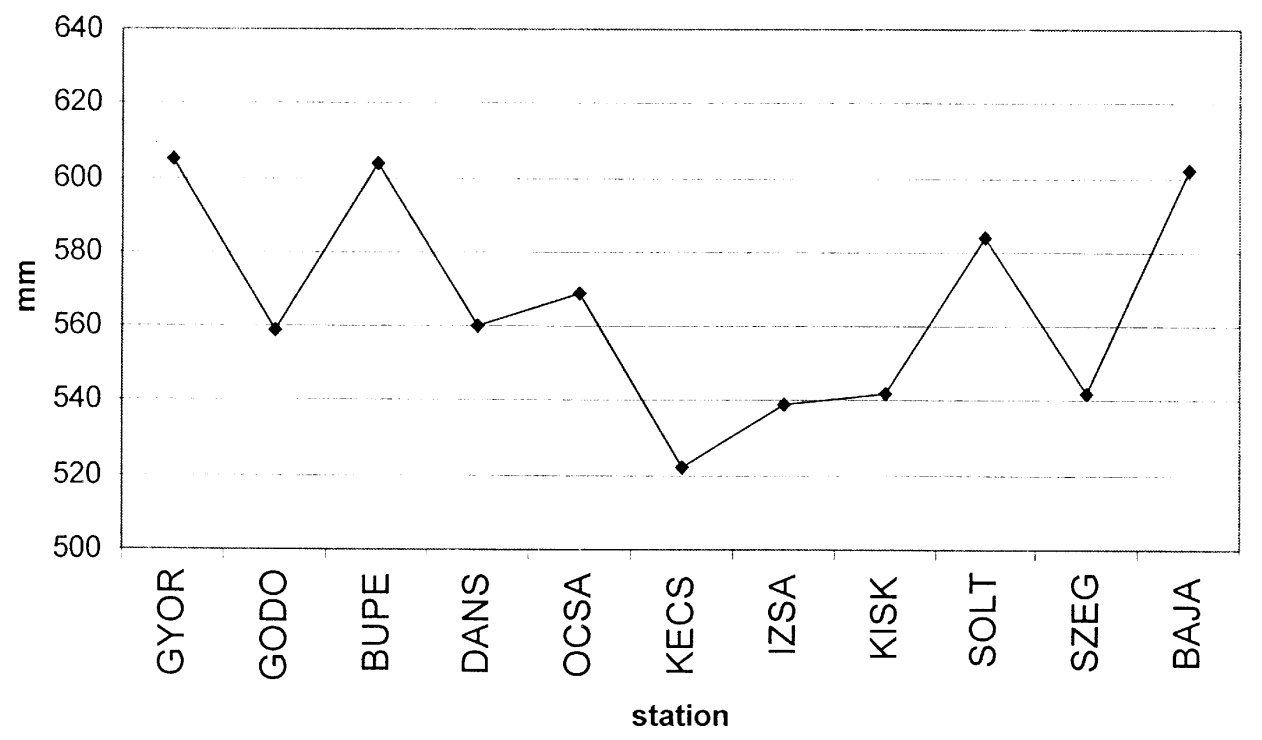

Fig. 3. Mean annual precipitation (1901-1970) at eleven stations 
The trends detected on the basis of the mean annual precipitation are investigated in detail based on the shares of the precipitation year types (Figs 5 and 6).
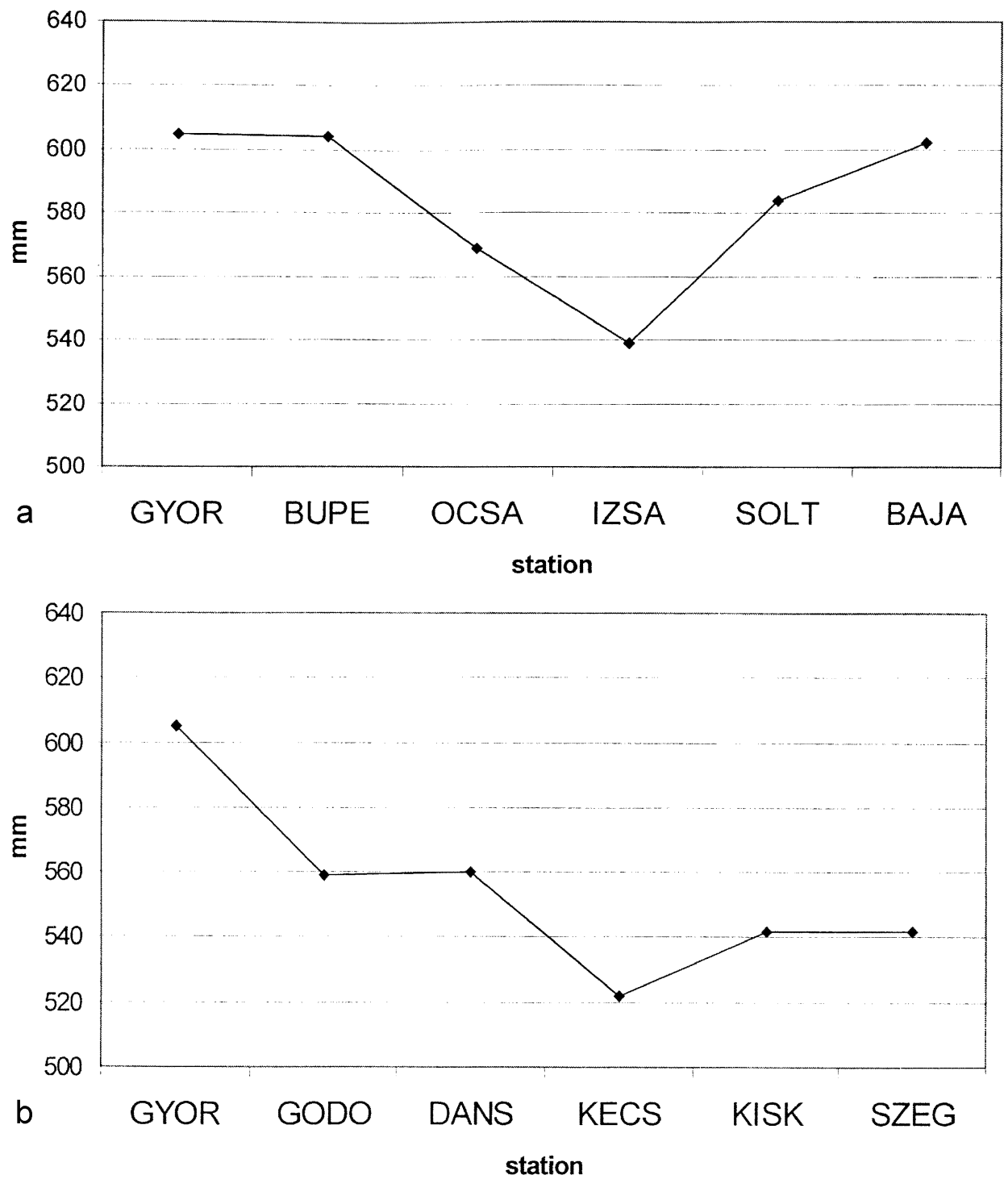

Fig. 4. a = Mean annual precipitation (1901-1970) at the western stations of the Danube-Tisza Mid-Region. $b=$ Mean annual precipitation (1901-1970) at the eastern stations of the Danube-Tisza Mid-Region 

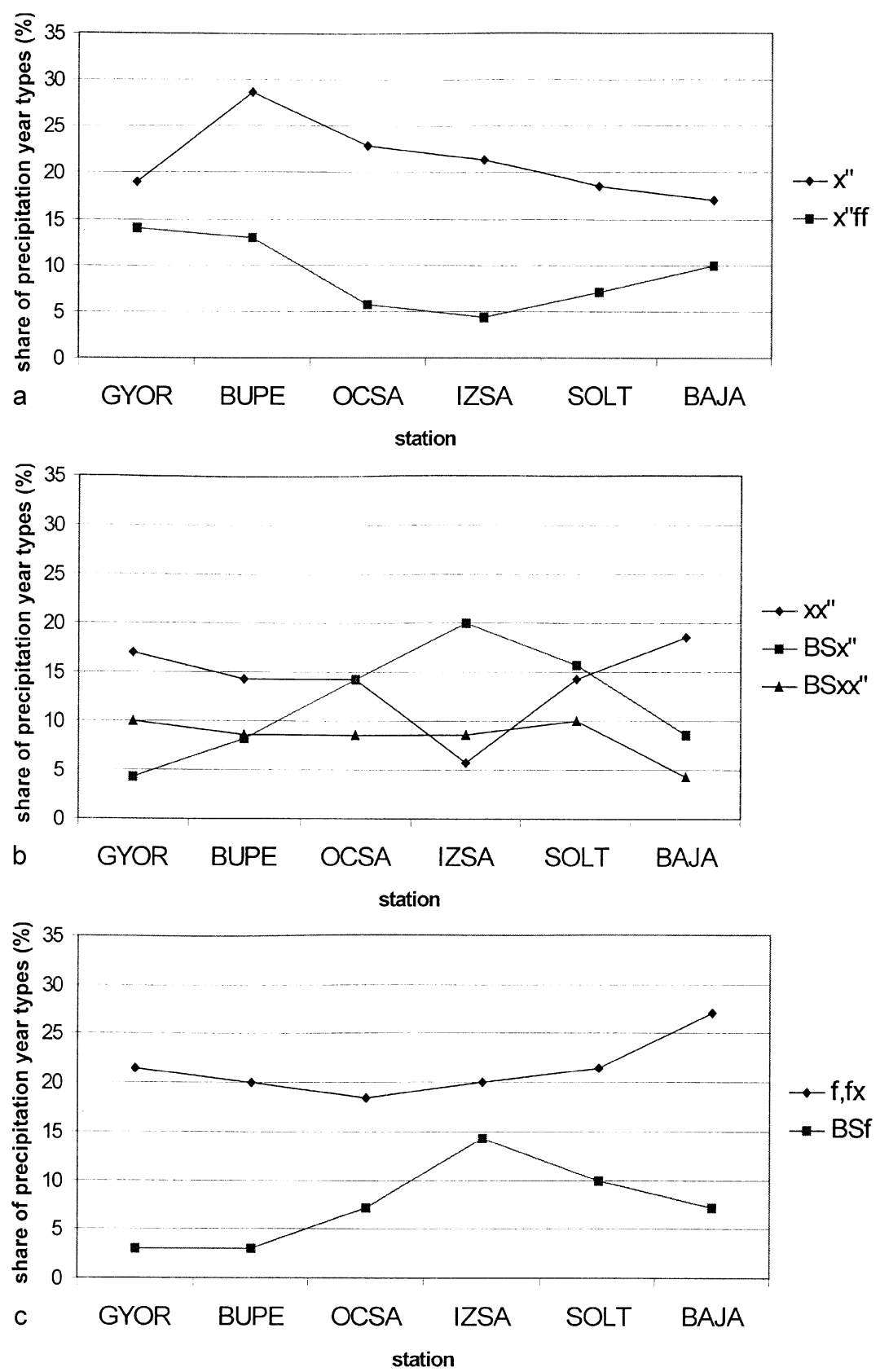

Fig. 5. a = Share of Atlantic-sub-Mediterranean years at the western stations of the Danube-Tisza Mid-Region. $b$ = Share of Pontic-sub-Mediterranean years at the western stations of the Danube-Tisza Mid-Region. c = Share of European-continental years at the western stations of the Danube-Tisza Mid-Region 

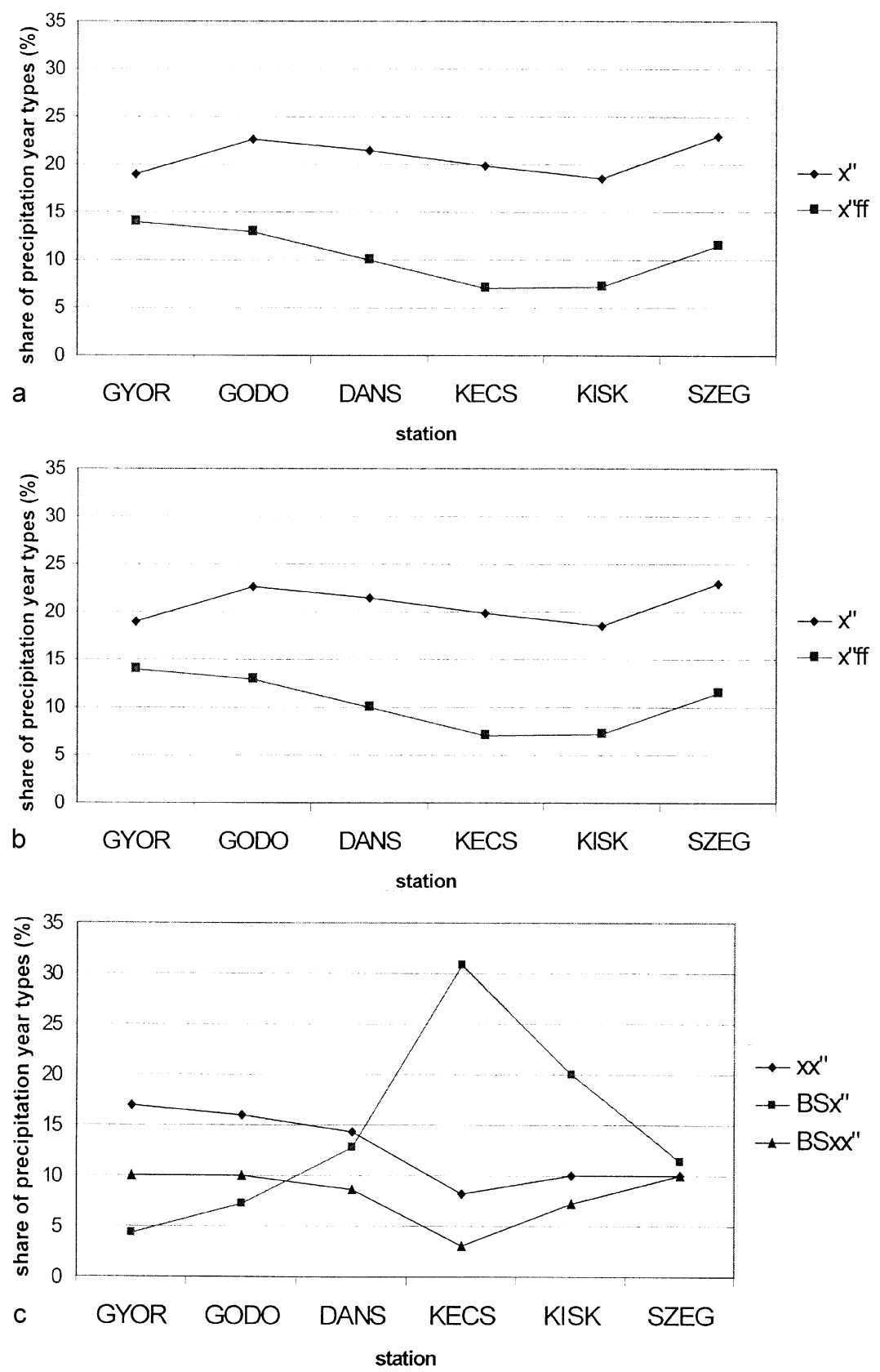

Fig. 6. a = Share of Atlantic-sub-Mediterranean years at the eastern stations of the Danube-Tisza Mid-Region $b=$ Share of Pontic-sub Mediterranean years at the eastern stations of the Danube-Tisza Mid-Region c = Share of European-continental years at the eastern stations of the Danube-Tisza Mid-Region 
The trends in Figures 5a and 6a are just slightly different, the difference is the increase of the share of relatively dry $(600-700 \mathrm{~mm})$ Atlantic-sub-Mediterranean $x^{\prime \prime}$ years at the southern part of the eastern region. Meanwhile, the share of wetter (750-900 mm) Atlantic-sub-Mediterranean $x^{\prime \prime} f f$ years is consistently lower at the western regions.

The share of the wet (550-650 mm) Pontic-sub-Mediterranean $x x^{\prime \prime}$ years is about the same at the northern parts at east and west, which is followed by a marked decrease towards the central parts. While the frequency of this type increases further south at the western part of the Danube-Tisza Mid-Region, it remains low at the eastern part (Figs $5 b$ and $6 b$ ).

The frequency of $\boldsymbol{B S} \boldsymbol{x}^{\prime \prime}$ years characterised by dry summers and low annual rainfall $(400-450 \mathrm{~mm})$ reaches a very high value at both stations (IZSA - Izsák, KECS - Kecskemét) of the central region. Its frequency is higher at the eastern station than at the western one. The frequency of this type decreases rapidly toward south in both cases. $B S \boldsymbol{X x}$ " years described by late autumn maximum and low annual precipitation show different trends geographically. Their share decreases at the south part of the western region, while it increases at the same part of the eastern region.

The share of $f$ and $f x$ year-types of the European-continental group, which have typically higher annual rainfall $(550-750 \mathrm{~mm})$ and summer precipitation maximum, changes differently along the two gradients from north to south. At the eastern part of the Danube-Tisza Mid-Region, their share shows a strong decrease followed by a slight increase, while at the western part the decrease is small and is followed by a gradual increase.

The share of continental steppe-like $\boldsymbol{B S} \boldsymbol{f}$ years described by low annual precipitation (400-450 $\mathrm{mm}$ ) increases gradually along the eastern transect from north to south, while it peaks at the central part and shows a considerably decrease to both north and south along the western transect.

Based on the precipitation distribution, our results support the earlier finding that the climate of the Danube-Tisza Mid-Region is basically sub-Mediterranean (cf. Borhidi 1961, 1981), but is significantly influenced by the effect of continental steppe-climate. A special combination of the two major climate types forms the precipitation distribution of the region. Sub-Mediterranean years with summer precipitation minimum and European-continental years with summer precipitation maximum have a similar frequency. Within both major climate types, however, year types with low annual precipitation have the highest frequency in the region.

The transitional climatic conditions are suitable for the development and persistence of both forest and steppe vegetation. In this term, the vege- 
tation of the region is sub-Mediterranean forest-steppe. This finding provide further support to those earlier results that the potential vegetation of the region is neither true steppe nor closed forest (Soó 1959, Borhidi 1961, Zólyomi et al. 1992a, 1992b).

The current broad extent of the treeless area in the central parts of the Danube-Tisza Mid-Region should be considered as a joint effect of edaphic conditions (Holocene sand cover of varying depth) that favours steppe regionally or locally, and the human deforestation activity.

It is important to note that the decrease in the precipitation and the increase in the frequency of years with dry summers are more significant at the eastern part of the Danube-Tisza Mid-Region than at the western part. Accordingly, this difference within the region should be considered in the interpretation of vegetation patterns. We also emphasise that our results are valid at the scale of the Danube-Tisza Mid-Region; different methods will be needed in finer scale investigations.

Acknowledgements - The author thanks G. Fekete, A. Borhidi, E. Kovács-Láng, R. Aszalós, Gy. Kröel-Dulay, D. Krasser and E. Ruprecht for their suggestions and comments. Supported by the Hungarian Scientific Research Fund (OTKA F 026458).

\section{REFERENCES}

Bartha, S., Kertész, M., Kovács-Láng, E., Coffin, D. P., Gosz, J. R., Glenn, S., Collins, S. L., Rédei, T., Hochstrasser, T., Kröel-Dulai, Gy., Hahn, I., Ódor, P., Harris, W., Campetella, D., Kun, A., Ittzés, P. and Bokros, Sz. (1999): Cross-site comparison of grassland diversity. - In: Kovács-Láng E., Molnár, E., Kröel-Dulay, Gy. and Barabás, S. (eds): Long term ecological research in the Kiskunság, Hungary. Kiskun LTER, MTA ÖBKI, Vácrátót, pp. $42-44$.

Borhidi, A. (1961): Klimadiagramme und Klimazonale Karte Ungarns. - Annals. Univ. Sci. Budapest., Sect. Biol., 4: 21-50.

Borhidi, A. (1981): Az éghajlat. (The climate.) - In: Hortobágyi, T. and Simon, T. (eds): Növényföldrajz, társulástan és ökológia. (Phytogeography, phytocoenology and plant ecology.) Tankönyvkiadó, Budapest, pp. 352-368.

Borhidi, A. (1993): Characteristics of the climate of the Danube-Tisza Mid-Region. - In: SzujkóLacza, J. and Kováts, D. (eds): The flora of the Kiskunság National Park. Hungarian Natural History Museum, Budapest, pp. 9-20.

Borhidi, A. (1998): Kerner és az Alföld növényföldrajza mai szemmel. (Actual considerations about Kerner and the phytogeography of the Hungarian Lowland.) - Kanitzia 6: $7-16$.

Fekete, G. (1965): Die Waldvegetation im Gödöllőer Hügelland. - Akadémiai Kiadó, Budapest, $223 \mathrm{pp}$. 
Fekete, G., Kun, A. and Molnár, Zs. (1999a): Chorológiai gradiensek a Duna-Tisza közi erdei flórában. (Chorological gradients of the forest flora at the Danube-Tisza Mid Region.) - Kitaibelia 4: 343-346.

Fekete, G., Molnár, Zs., Kun, A. and Botta-Dukát, Z. (1999b): Landscape dependence of steppe grasslands along a climate gradient. - Abstracts, 42nd IAVS Symposium Conference, Bilbao, Spain, p. 53.

Fekete, G., Molnár, Zs., Kun, A. and Botta-Dukát, Z. (2000): Landscapes and vegetation along a climatic and edaphic gradient: variability of the sandy grasslands in the Hungarian Region. Proceedings of the ILTER Regional Workshop, 22-25 June, 1999, “Cooperation in long term ecological research in central and eastern Europe".

Hajósy, F., Kakas, J. and Kéri, M. (1975): A csapadék havi és évi összegei Magyarországon a mérések kezdetétől 1970-ig. (Monthly and annual sums of precipitation in Hungary from the first observations until 1970.) - OMSZ, Budapest, vol. 42.

Horvat, I., Glavač, V. and Ellenberg, H. (1974): Vegetation of southeast Europe. (Vegetation Südosteuropas.) - G. Fischer, Jena, 768 pp.

Kovács-Láng, E., Kertész, M., Kröel-Dulay, Gy., Mika, J., Rédei, T., Rajkai, K., Hahn, I. and Bartha, S. (1999): Effects of a climate gradient on sand vegetation. - In: Kovács-Láng E., Molnár, E., Kröel-Dulay, Gy. and Barabás, S. (eds): Long term ecological research in the Kiskunság, Hungary. Kiskun LTER, MTA ÖBKI, Vácrátót.

Köppen, W. (1918): Klimakunde. - Berlin, Leipzig, 137 pp.

Köppen, W. (1929): Typische und Übergangs Klimate. - Meteorologische Zeitschrift. 45: 121-126.

Russel, R. J. (1934): Climatic Years. - The Geographical Review 24: 92-103.

Soó, R. (1959): Streitfragen über die Entstehung der Vegetation des Alföld und ihre heutige Beurteilung. (Az Alföld növényzete kialakulásának mai megítélése és vitás kérdései.) - Földr. Ért. 8: 1-26.

Zólyomi, B. (1958): Budapest és környékének természetes növénytakarója. (The natural vegetation of Budapest and its environs.) - In: Pécsi, M., Marosi, S. and Szilárd, J. (eds): Budapest természeti képe. Akadémiai Kiadó, Budapest, pp. 509-642.

Zólyomi, B. (1973-1974): Natürliche Vegetation. Natural Vegetation. Végétation Naturelle. Estestvennaja Rastitelnost. (Ungarischer Teil.) - In: Niklfeld, H. (ed.): Atlas der Donauländer Österreichisches Ost und Südosteuropa Institut. Wien, No. 171.

Zólyomi, B., Kéri, M. and Horváth, F. (1992a): A szubmediterrán éghajlati hatások jelentôsége a Kárpát-medence klímazonális növénytársulásainak összetételére. (Impacts of sub-Mediterranean climatic influences on the composition of climatic zonal plant associations in the Carpathian Basin.) - Memorial volume to Kabos Hegyfoky. Debrecen, Túrkeve, pp. 60-74.

Zólyomi, B., Kéri, M. and Horváth, F. (1992b): Changes and fluctuation of a zonal sub-Mediterranean hairy oakwood and the sub-Mediterranean climate in time and space in the Pannonian Basin responses of forest ecosystems to environmental changes. - In: Teller, A., Mathy, P. and Jeffers, J. N. R. (eds): Elsevier applied sciences. London, New York, pp. 582-585.

Zólyomi, B., Kéri, M. and Horváth, F. (1997): Spatial and temporal changes in the frequency of climatic year types in the Carpathian Basin. - Coenoses 12(1): 33-41. 